\title{
A Study on Occupational Stress among Nurses in Erode District, Tamil Nadu
}

\author{
R. Gopinath ${ }^{1}$, A. Chitra ${ }^{2}$ and R. Kalpana ${ }^{3}$ \\ ${ }^{1}$ D. Litt. (Business Administration), Researcher, Madurai Kamaraj University, Tamil Nadu, India \\ ${ }^{2}$ Associate Professor, Ganesh School of Business Management, Salem, Tamil Nadu, India \\ ${ }^{3}$ Assistant Professor, PG \& Research Department of Management, \\ Srimad Andavan Arts \& Science College (Autonomous), Trichy, Tamil Nadu, India \\ E-mail: dr.raju.gopinath@gmail.com, ananthnarayanchitra@gmail.com, pana.kal7@gmail.com
}

\begin{abstract}
Nursing is considered one among the stressful professions. Over workload inadequate felicities, and sometimes the profession itself would be the cause of the stress to the Nurses. The professional stress of the Nurses creates so many adverse effects and creates negative effects to the persons who depend on the Nurses as the Occupational Stress reduces their concentration in medication. These made this study as essential one. Weiman Occupational Stress Scale was used to construct questionnaire to collect the data from Nurses and required statistical tools were used to analyses the relationship of stress causers with demographic factors and the impact of stress on the physical and mental health of the respondents. The results of the study were found that the Nurses were confronting high level of Occupational Stress during the period of Lockdown. The main stressors were over workload, in adequate felicities, fear of getting affected by the Corona virus and inadequate quality time with family. The demographic factors have significant relationship with the causes of Occupational Stress and the impact of Occupational Stress on the physical, emotional and Psychological state of Nurses is also immense. So enough measures have to be taken to moderate the stress level of Nurses as it is required for Nurses themselves and the patients depending them.

Keywords: Occupational Stress, Nurses
\end{abstract}

\section{INTRODUCTION}

In recent decades the concept of Occupational Stress of the Nurses is getting the attention of researchers due to its vast impact not only on the side of Nurses but which may have impact on the patients also. Stress is denoted as a kind of unpleasant emotional state, which is expected to create job insecurity, reduce concentration and productivity, low level of job satisfaction (Gopinath, 2014 b) and lack of autonomy and even cause health issues. The changes in working style also cause additional stress. Pertaining stress cannot be subsided event through transfer and promotion (Gopinath, 2016). Kyriacou (1978) defines stress is result of prolonged pressures that can't be controlled by the coping strategies that an individual. The American Psychological Association (2007) says that 52\% of employees having Occupational Stress may consider the option of refusing the promotion or leaving the job due the stress factors in organization. This indicates that the stress may lead to reduction in employee commitment and performance (Gopinath, 2020c).According Gopinath (2020a), low retention rate, is the prime indicator of low organizational commitment and occupational stress (Sivakumar \& Chitra, 2018). The employee's ability to manage stress in the workplace is the determinant of success or failure of an organization. According to International Labour Organization Occupational Stress reduces the quality of nursing care and increases the chances of making errors and prolonged stress would be the cause for development of physical disorders of the musculoskeletal and cardiovascular diseases (Milutinovic et al., 2012) Research recent decades shows that, the symptoms of Occupational Stress appear to be rising among Nurses which has been referred to several factors ranging from downsizing, restructuring, and merging to role boundary and responsibility (Nedd, 2006). Though the Occupational Stress of Nurses has adverse effect on themselves and the patients, this paper is an attempt to study the Occupational Stress of Nurses and suggest some measure to mitigate the level of stress and the physical, emotional, and Psychological consequences to Nurses. The task of acquiring sound and credible employees belongs to the HRD Practices influencing Job satisfaction. In an increasingly competitive organization are largely dependent on their employees for success (Gopinath \& Shibu, 2016).

\section{REVIEW OF LITERATURE}

Occupational Stress has become one of the most important adverse constituents in the modern world (Lu et al., 2003). Occupational Stress, is also called as job stress, has been defined as the experience of negative emotional states such as frustration, worry, anxiety and depression because of work related factors (Kyriacou, 2001). Emotional misbalancing will create health related issues also (Chitra \& Vanadhi, 2021) in particular, is the inability to cope with the pressures in a job, because of a poor fit between someone's capability and his/her work load and conditions (HolmlundRytkonen \& Strandvik, 2005; Gopinath \& Chitra, 2020; Sivakumar \& Chitra, 2017).

According to Jahanzeb (2010), Technological changes, information overload, and demand for greater productivity, mass retrenchment, fierce competition and uncertain future are the prime sources of extreme stress. Stress basically comprises the relationship between individuals and their 
environment, when the environment considered as challenging or threatening their well-being. Stressors are objects, stress is created (Gopinath, 2014 a). And the response for the stress is the form of physiological such as rapid heart rate, increased blood pressure and even psychological like anger and fear.

The people who have the capability to manage their emotions may handle the stress better (Chitra, 2020) failed may face severe consequences like cardio vascular diseases, lack of concentration etc., (Gopinath \& Ganesan, 2014). Several studies have shown that Occupational Stress can lead to vigorous negative consequences to the individual and as well as to the workplace (Gopinath, 2011 a; Sivakumar \& Chitra, 2017).

According to Chapman, Occupational Stress reduces productivity, increases management pressures and makes people sick in many ways. Gopinath (2020 d) has conducted study on role of employees' attitude in work place and found the employees' attitude is strongly influenced by their job satisfaction, job involvement and organisational commitment. Gopinath (2020 f) concluded that positive and significant relationship between the five dimensions of Emotional Intelligence (self-awareness, managing emotions, motivating self, empathy, social skills) and SelfActualization. Occupational Stress in Nurses is significant for a number of reasons. The prime one is Occupational Stress leads to health-related issues in Nurses and decreases their efficiency (Olayinka \& Osamudiamen, 2013) and their stress may cause emotional exhaustion which may leads to negative feeling on the patients under their care.

Researches has highlighted that, enhancement of level of self-actualization may also support to reduced occupational stress (Gopinath, 2020b). Occupational Stress Nurses affect their health and increases absenteeism, attrition rate, injury claims, and errors in treating the patients. This Kinds of notable implicating adverse effects of Occupational Stress of Nurses made this study as essential one (Gopinath, 2011b). Gopinath (2020 e) found that the influence of individual factor of Emotional Intelligence is different with Self- Actualization, specifically the factor self -awareness and social skills. Gopinath et al., (2021) inferred that faculties' apprehension of enhancement of Knowledge Management increases their level of Occupational Stress.

\section{OBJECTIVES AND HYPOTHESIS}

1. To find the relationship between demographic factors and causes of Occupational Stress of the Nurses.

2. To find the physical, Emotional and Psychological effects Occupational Stress among the Nurses.

The following hypothesis has been formulated for this study.

$H_{0}$ : There is no significant association between demographic factors and causes of Occupational Stress.

\section{RESEARCH METHODOLOGY}

\section{A. Research Design}

The study employed a descriptive research design. Weiman Occupational Stress Scale was used to collect primary data from the Nurses. Purposive sampling technique was used to select 142 Nurses of Erode District of Tamil Nadu. Descriptive and Inferential statistical tools were used to analyses the collected data.

\section{B. Ethical Statement}

Formal approval was received from the concern Hospital authorities. The prepared questionnaire was submitted 2 weeks before the data collection and the due concern of hospital authorities was received and the personal details of the respondent were also kept confidential.

\section{ANALYSIS}

\section{A. Demographic Factors and Causes of Occupational Stress}

TABLE I IMPACT OF GENDER ON CAUSES OF OCCUPATIONAL

\begin{tabular}{|l|c|c|c|}
\hline \multicolumn{1}{|c|}{ Causes } & $\begin{array}{c}\text { t- } \\
\text { Value }\end{array}$ & $\begin{array}{c}\text { P- } \\
\text { Value }\end{array}$ & Result \\
\hline $\begin{array}{l}\text { Inadequate } \\
\text { Motivation }\end{array}$ & 1.23 & 0.022 & Significant @5\% \\
\hline Inadequate Staffing & 2.02 & 0.000 & $\begin{array}{c}\text { Highly significant } \\
@ 1 \%\end{array}$ \\
\hline $\begin{array}{l}\text { Handling large } \\
\text { number of patients }\end{array}$ & 1.23 & 0.000 & $\begin{array}{c}\text { Highly significant } \\
@ 1 \%\end{array}$ \\
\hline Lack of break time & 3.21 & 0.002 & Significant @5\% \\
\hline Frequent night duty & 2.12 & 0.000 & $\begin{array}{c}\text { Highly significant } \\
@ 1 \%\end{array}$ \\
\hline
\end{tabular}

Based on the table I show that the P-Value is less than 0.01 ; hence the null hypothesis is rejected at $1 \%$ level of significance, since there is highly significant relationship between stress due Inadequate Staffing Handling large number of patients and stress related to frequent night duty. And P-Value is less than 0.05 in case of relationship between gender and stress related to Inadequate Motivation and stress related to Lack of break time and gender. Hence the null hypothesis is rejected at $5 \%$ level of significance.

So there is a significant relationship between gender and Inadequate Motivation and stress related to Lack of break time. As the female are need to work in hospital and also in home, they are facing more stress due to inadequate staffing Handling large number of patients and stress related to frequent night duty and increases their level of fatigue. As Nursing job itself requires lot of patience, the Nurses expect a kind of motivation even form an unnamed and a breather during the working hours. If their expectations are not met out, that will become a significant cause of Occupational Stress. 


\section{B. Age, Experience, Salary and Family Size and Causes of Occupational Stress}

From the table II results show that the P-Value is less than 0.01 in case of Inadequate Motivation, handling large number of patients, Lack of break time, Frequent night duty the null hypothesis is rejected at $1 \%$ level of significance, Hence the is a significant relationship between Age of the respondent and stress caused by Inadequate Motivation, Handling large number of patients, Lack of break time, and Frequent night duty. Since the P-Value is less than 0.05 in case of Inadequate Staffing, the null hypothesis is rejected at $5 \%$ level of significance; hence there is a relationship between Age and Inadequate Staffing.
Since the P-Value is less than 0.01 in case of handling large number of patients and frequent night duty, the null hypothesis is rejected at $1 \%$ level of significance; hence there is highly significant relationship between experience of the respondents and the stress caused by handling large number of patients and frequent night duties. Since The PValue is less than 0.05 null hypothesis is rejected at $5 \%$ level of significance in case of Inadequate Motivation, Inadequate Staffing and Lack of break time. Hence there is a relationship between experience of the respondents and the stress caused by Inadequate Motivation, Inadequate Staffing and Lack of break time.

TABLE II IMPACT OF AGE, EXPERIENCE, SALARY AND FAMILY SIZE AND CAUSES OF OCCUPATIONAL STRESS

\begin{tabular}{|c|l|c|c|c|}
\hline Factor & \multicolumn{1}{|c|}{ Causes of Stress } & F-Value & P-Value & Result \\
\hline \multirow{5}{*}{ Age } & Inadequate Motivation & 2.32 & 0.001 & Significant @1\% \\
\cline { 2 - 5 } & Inadequate Staffing & 3.45 & 0.002 & Significant @5\% \\
\cline { 2 - 5 } & $\begin{array}{l}\text { Handling large number of } \\
\text { patients }\end{array}$ & 2.31 & 0.001 & Significant @1\% \\
\cline { 2 - 5 } & Lack of break time & 2.56 & 0.001 & Significant @1\% \\
\cline { 2 - 5 } & Frequent night duty & 3.21 & 0.001 & Significant @1\% \\
\hline \multirow{5}{*}{ Experience } & Inadequate Motivation & 4.21 & 0.021 & Significant @5\% \\
\cline { 2 - 5 } & Inadequate Staffing & 3.32 & 0.002 & Significant @5\% \\
\cline { 2 - 5 } & $\begin{array}{l}\text { Handling large number of } \\
\text { patients }\end{array}$ & 2.67 & 0.001 & Significant @1\% \\
\cline { 2 - 5 } & Lack of break time & 1.98 & 0.003 & Significant @5\% \\
\cline { 2 - 5 } & Frequent night duty & 2.21 & 0.001 & Significant @1\% \\
\hline \multirow{5}{*}{ Falary } & Inadequate Motivation & 3.56 & 0.001 & Significant @1\% \\
\cline { 2 - 5 } & Inadequate Staffing & 2.01 & 0.002 & Significant @5\% \\
\cline { 2 - 5 } & $\begin{array}{l}\text { Handling large number of } \\
\text { patients }\end{array}$ & 3.07 & 0.001 & Significant @1\% \\
\cline { 2 - 5 } & Lack of break time & 3.27 & 0.001 & Significant @1\% \\
\cline { 2 - 5 } & Frequent night duty & 2.43 & 0.001 & Significant @1\% \\
\cline { 2 - 5 } & Inadequate Motivation & 2.56 & 0.002 & Significant @5\% \\
\cline { 2 - 5 } & Inadequate Staffing & 3.45 & 0.003 & Significant @5\% \\
\cline { 2 - 5 } & $\begin{array}{l}\text { Handling large number of } \\
\text { patients }\end{array}$ & 2.32 & 0.001 & Significant @1\% \\
\cline { 2 - 5 } & Lack of break time & 3.42 & 0.001 & Significant @1\% \\
\hline \multirow{5}{*}{ Frequent night duty } & 1.87 & 0.001 & Significant @1\% \\
\hline
\end{tabular}

Since the P-Value is less than 0.01 in case of Inadequate Motivation, handling large number of patients, Lack of break time, Frequent night duty the null hypothesis is rejected at $1 \%$ level of significance, Hence the is a significant relationship between Age of the respondent and stress caused by Inadequate Motivation, Handling large number of patients, Lack of break time, and Frequent night duty. Since the P-Value is less than 0.05 in case of Inadequate Staffing, the null hypothesis is rejected at 5\% level of significance; hence there is a relationship between Age and Inadequate Staffing.
From the table II result shows that the P-Value is less than 0.01 in case of handling large number of patients and frequent night duty, the null hypothesis is rejected at $1 \%$ level of significance; hence there is highly significant relationship between experience of the respondents and the stress caused by handling large number of patients and frequent night duties. Since The P-Value is less than 0.05 null hypothesis is rejected at $5 \%$ level of significance in case of Inadequate Motivation, Inadequate Staffing and Lack of break time. Hence there is a relationship between experience of the respondents and the stress caused by Inadequate Motivation, Inadequate Staffing and Lack of 
break time. Since the P-Value is less than 0.01 in case of Inadequate Motivation, Handling large number of patients, Lack of break time and Frequent night duty the null hypothesis is rejected at $1 \%$ level of significance, hence there is a highly significant relationship between salary of the respondent and the stress caused by Inadequate Motivation, Handling large number of patients, Lack of break time and Frequent night duty and since the P-Value is less than 0.05 in case of Inadequate Staffing the null hypothesis is rejected at $5 \%$ level of significance hence there is a significant relationship between salary of the respondent and the stress caused by Inadequate Staffing.

Since the P-Value is less than 0.01 in case of Handling large number of patients, Lack of break time, frequent night duty, the null hypothesis is rejected at $1 \%$ level significance. Hence there is a highly significant relationship between family size and handling large number of patients, Lack of break time, frequent night duty. Since the P-Value is less than 0.05 in case of Inadequate Motivation and Inadequate Staffing, the null hypothesis is rejected at 5\% Level of significance hence there is a relationship between family size and stress caused by Inadequate Motivation and Inadequate Staffing.

\section{Physical, Emotional and Psychological effects Occupational Stress among the Nurses}

Based on the table III results show that, while analyzing about the physical, Emotional and Psychological effects Occupational Stress of the respondent, the respondents are permitted to select as many choices as they want, so that a respondent can choose all the effects they encounter due to Occupational Stress. Most of the respondents feel that they have headache and fatigue as physical issue, over reaction to a situation and frustration as emotional issue, lack of concentration and withdrawal as Psychological issue.

TABLE III PHYSICAL, EMOTIONAL AND PSYCHOLOGICAL EFFECTS OCCUPATIONAL STRESS AMONG THE NURSES

\begin{tabular}{|c|c|}
\hline Stress & Number of responses \\
\hline \multicolumn{2}{|c|}{ Physical Stress } \\
\hline Headache & 56 \\
\hline Insomnia & 23 \\
\hline Fatigue & 52 \\
\hline Blood Pressure & 41 \\
\hline Ulcer & 27 \\
\hline \multicolumn{2}{|c|}{ Emotional Stress } \\
\hline Anxiety & 35 \\
\hline Over Reaction & 42 \\
\hline Frustration & 65 \\
\hline Night terrors & 34 \\
\hline \multicolumn{2}{|c|}{ Psychological Stress } \\
\hline Forgetfulness & 45 \\
\hline Lack of Concentration & 63 \\
\hline Withdrawal & 54 \\
\hline
\end{tabular}

\section{Rank of Factors Causing Stress}

TABLE IV RANK OF FACTORS CAUSING STRESS

\begin{tabular}{|l|c|c|}
\hline \multicolumn{1}{|c|}{ Factor } & Mean & Rank \\
\hline Inadequate Motivation & 4.34 & 5 \\
\hline Inadequate Staffing & 3.71 & 4 \\
\hline $\begin{array}{l}\text { Handling large number of } \\
\text { patients }\end{array}$ & 3.58 & 3 \\
\hline Lack of break time & 3.32 & 2 \\
\hline Frequent night duty & 3.03 & 1 \\
\hline
\end{tabular}

From the table IV shows that, when analyzing about rank of factors causing Occupational Stress of Nurses, the respondents ranked frequent night duty as the most stress causing factor followed by lack of beak time, handling large number of patients, inadequate staffing and inadequate motivation as least stress causing factor.

\section{FINDINGS OF THE STUDY}

1. Female are confronting more stress than Male (Gopinath, 2011c) due to inadequate Staffing Handling large number of patients and stress related to frequent night duty, because these factors made them mentally and physically tired and create more stress in their work.

2. The respondent who are all above 40 years, are expecting Motivation, handling nominal number of patients, adequate break time, considerably less night duties and adequate Staffing. Absence of those factors makes them stressed. Whereas respondents of less than 40 years are able to cope up even though those factors are not available.

3. The respondents, who have less experience, get fatigue when they tend to handle large number of patients and while having frequent night duties. And the absence of motivation, inadequate staffing and insufficient break time will also have influence on Occupational Stress of the Nurses.

4. Even though the respondents are appropriately paid, they expect kind of motivational words from the management, and since they are appropriately paid the management should not expect them to Handle are number of patients, make them to work without adequate break time ask them to handle Frequent night duties and make them to work in sufficient staffing. Those kind of organisational expectations make them stressed.

5. Obviously the respondents having large family size incline to have more responsibilities and he himself encounters some personal stress (Gopinath, $2011 \mathrm{~d}$ ). In working place the respondents form large family expect a considerable level of motivation, adequate number of Staffs to perform his duties, optimum workload, sufficient break time and right amount of day and night duties. Non fulfilment of above expectations may induce their level of stress as they are already expected to have personal stress. 
6. Most of the respondents feel they encounter lack of concentration, frustration, Headache, Withdrawal and Fatigue as the prime effect of Occupational Stress.

7. Frequent night duty is ranked as top stress causer and lack of adequate motivation is ranked as least stress causer.

\section{DISCUSSION}

Nursing the profession by nature considered as more stressful than other professions. So the management should take care that any other factors apart from the job itself should not create stress to the Nurses. Gopinath \& Kalpana, (2020) concluded that Job Involvement gives good opportunity for advancement to fulfill the personal life goals. For that purpose, they have taken care of certain factors like consistent motivation to the employees, employing adequate number of staffs, allocating adequate number of patients to the Nurses, proving adequate break time, right number of night duties. Proper arrangement of above factors will make the Nurses composed and serve the patients with more patience and catch the doctor's directions correctly. This will support speedy recovery of the patients which indirectly enhance the reputation of the hospital (Gopinath \& Kalpana, 2014). In today's competitive scenario, poised nursed would become the competitive edge for the hospitals and encourage the patients to have an enduring relationship with the hospital.

\section{CONCLUSION}

The above study reveals Occupational Stress has significant impact on the physical, emotional and Psychological wellbeing of the Nurses and the demographic factors also has significant relationship with the causes of the stress. Regardless of demographic factors almost all the respondents are pertaining to Occupational Stress. This confirms the opinion of people, nursing as a stress full profession. When considering the outcome of stresses, almost all the respondents are suffered by at least two issues of stresses. No respondent has reported that he/she is not affected by any of the issues. Summary of these results shows the extreme level of Occupational Stress of Nurses, this has to be concentrated and effective measures has to be taken to alleviate the level of stress of the nurse, because their stress not only has impact on themselves but also on the patients who depends on them.

\section{REFERENCES}

[1] Chitra, A. (2020). Impact of Socio-Economic Status of Parents on the Emotional Intelligence of Generation Alpha Kids. International Journal of Latest Technology in Engineering Management \& Applied Science, 9(5), 46-49.

[2] Chitra, A., \& Vanadhi, R. (2021). A Literature Review of Emotional Intelligence. Wesleyan Journal of Research, 14 (1(10)), 159-166.

[3] Gopinath, R. (2014 a). Reduction of Executive Stress by Development of Emotional Intelligence - A study with reference to CMTS, BSNL, TN circle. International Journal of Management Research and Development, 4(2), 23-40.
[4] Gopinath, R. (2014 b). Impact of Stress Management by Development of Emotional Intelligence in CMTS, BSNL, Tamil Nadu Circle-A Study. International Journal of Management Research and Development, 4(1), 53-67.

[5] Gopinath, R. (2016). Is Promotion and Transfer helps to Employee's Job Satisfaction? An Empirical Study at BSNL with special reference in three different SSAs using modeling. Asian Journal of Management Research, 6(4), 277-285.

[6] Gopinath, R. (2020 a). Job involvement and organizational commitment of academic leaders in Tamil Nadu universities - A relationship study with structural equation modeling. Journal of Critical Reviews, 7(19), 1857-1864.

[7] Gopinath, R. $(2020$ b). Prominence of Self-Actualization in Organization. International Journal of Advanced Science and Technology, 29(3),11591 - 11602

[8] Gopinath, R. (2020 c). Impact of Academic Leaders' SelfActualization on Organisational Commitment in Tamilnadu Universities - Through Structural Equation Modelling (Sem). TEST Engineering and Management, 83, 24898- 24904.

[9] Gopinath, R. (2020 d). Role on Employees' Attitude in Work Place. GEDRAG \& Organisatie Review, 33(2), 1461-1475.

[10] Gopinath, R. (2020 e). Emotional Intelligence's influence on SelfActualization- A study among Academic Leaders of Tamil Nadu Universities. International Journal of Management, 11(7), 13141323.

[11] Gopinath, R. (2020 f). Study on Relationship between Emotional Intelligence and Self Actualization among Academicians of Tamil Nadu Universities. International Journal of Psychosocial Rehabilitation, 24(2), 5327 - 5337.

[12] Gopinath, R., \& Chitra, A. (2020). Emotional Intelligence and Job Satisfaction of Employees' at Sago Companies in Salem District: Relationship Study. Adalya Journal, 9(6), 203-217.

[13] Gopinath, R., \& Ganesan, V. (2014). Stress Management by Development of Emotional Intelligence, A study with reference to CMTS, BSNL Tamil Nadu Circle. Research Journal of Business Management, 8(3), 254-261.

[14] Gopinath, R., \& Kalpana R. (2014). Employees' Job Satisfaction Working At Hospitals in Perambalur District. Journal of Emerging Technologies and Innovative Research, 6(4), 220-225.

[15] Gopinath, R., \& Kalpana. R. (2020). Relationship of Job Involvement with Job Satisfaction. Adalya Journal, 9 (7), 306-315.

[16] Gopinath, R., \& Shibu, N.S. (2016). Few HRD Factors Influencing Job Satisfaction - A Study With Reference To BSNL, Three Different SSAs. International Journal of Management, 7(2), 379-384.

[17] Gopinath, R., Chitra, A., \& Kalpana. R. (2021). A Study on Relationship Between Knowledge Management and Occupational Stress, Journal of Contemporary Issues in Business and Government, 27(3), 1391-1397.

[18] Gopinath. R. (2011 a). A Study on Workplace Emotion Dimensions of Employees' in BSNL, Trichy SSA, Tamil Nadu Circle. Inventi Rapid: Human Resource, 2(2), 1-4.

[19] Gopinath. R. (2011 b). Employees' Workplace Emotions in Organizations, International Journal of Research in Commerce, Economics \& Management, 2(5), 132-137.

[20] Gopinath. R. (2011 c). Employees' Emotions in Workplace. Research Journal of Business Management, 4(2), 1-15.

[21] Gopinath. R. (2011 d). Emotion Patterns of Employees'-A Study with Reference to BSNL, Trichy SSA, Tamil Nadu Circle. Inventi Rapid: Human Resource, 2(2).

[22] Holmlund-Rytkonen, M. \& Strandvik, T. (2005). Stress in the business relationship. Journal of Business \& Industrial Marketing, 20(1), 12-22.

[23] International Labour Organization. World Labour Report. New York: International Labour Organization; 2005. Retrieved from http://www. inc.ch/psshiftwork.htm.

[24] Jahanzeb, H. (2010). The Impact of Job Stress on Job Satisfaction among Academic Faculty of a Mega Distance Learning Institution in Pakistan. A Case Study of Allama Iqbal Open University. Mustang Journal of Business \& Ethics, 1, 31-48.

[25] Kyriacou, C. (2001). Teacher stress: directions for future research. Educational Review, 53(1), 27-35.

[26] Lu, L., Kao, S. F., Chang, T. T., Wu, H. P., \& Cooper, C. L. (2011). Work/family demands, work flexibility, work/family conflict, and their consequences at work: A national probability sample in 
Taiwan. International Perspectives in Psychology: Research, Practice, Consultation, 1(S), 68.

[27] Milutinovic, D., Golubovic, B., Brkic, N., \& Prokes, B. (2012). Professional stress and health among critical care Nurses in Serbia. Archives of Industrial Hygiene and Toxicology, 63(2), 171180.

[28] Nedd, N. (2006). Perceptions of empowerment and intent to stay. Nursing economics, 24(1), 13-20.

[29] Onasoga, O. A., Osamudiamen, O. S., \& Ojo, A. A. (2013). Occupational stress management among Nurses in selected hospital in Benin City, Edo state, Nigeria. Eur J Exp Biol, 3(1), 473-81.

[30] Sivakumar, B. N., \& Chitra, A. (2017). A study on impact of emotional intelligence on teaching efficiency of management faculties. International Journal of Research in Management \& Social Science, 5(3), 54-58.
[31] Sivakumar, B. N., \& Chitra, A. (2017). Study on impact of Occupational Stress on employee job satisfaction of private higher secondary school teachers. Global Journal for Research Analysis, $6(2), 25-27$.

[32] Sivakumar,B. N., \& Chitra, A. (2018). Emotional Intelligence and Employee Retention- a Relationship Study on Employee's of SAIL Refractory Ltd. International Journal of Latest Technology in Engineering, Management \& Applied Science, 7(5), 113-115.

[33] Weiman, C. (1978). A Study of Occupational Stressors. Journal of Occupational Medicine, 19,119-122. 